\title{
Analisis Perbedaan Kinerja Keuangan Perusahaan Antara Sebelum Dan Sesudah Berpartisipasi Dalam Indonesian Suistanabillity Reporting Awards (ISRA)
}

\author{
Megi Oktriani Herman'1, Ulfi Maryati \\ ${ }^{1}$ Politeknik Negeri Padang \\ Email: Megioktriani17@gmail.com \\ ${ }^{2}$ Jurusan Akuntansi, Politeknik Negeri Padang \\ Email: ulfimaryati@gmail.com
}

\begin{abstract}
ABSTRAK
Penelitian ini bertujuan untuk menguji apakah terdapat perbedaan kinerja keuangan perusahaan antara sebelum dan sesudah berpartisipasi dalam ISRA. Penelitian ini menggunakan data sekunder. Variabel dalam penelitian ini adalah kinerja keuangan dari sisi profitability ratio yang mencakup return on asset (ROA), return on equity (ROE), net profit margin (NPM). Sampel penelitian ini terdiri dari 13 perusahaan dengan metode purposive sampling yaitu perusahaan yang menjadi partisipan Indonesian Sustainability Reporting Awards secara konsisten tiga tahun berturut-turut pada periode 2007-2011. Data pengumpulan sampel penelitian dapat diakses melalui website perusahaan dan website National Center of Sustainability Reporting dan perusahaan tersebut mempublikasikan Laporan Keuangan Tahunan pada tahun 2004-2014 yang dapat diakses melalui website perusahaan. Pengujian hipotesis dilakukan dengan teknik analisis paired sample t-test menggunakan software IBM SPSS versi 20 . Hasil penelitian menunjukkan bahwa tidak adanya perbedaan kinerja perusahaan antara sebelum dan sesudah berpartisipasi dalam Indonesian Sustainability Reporting Awards.
\end{abstract}

Kata kunci : Indonesian Suistanabiliity Reporting awards, Kinerja Keuangan Perushaaan, dan Profitabillity Ratio.

\begin{abstract}
This study aims to test whether there are differences in corporate financial performance between before and after participating in ISRA. This study uses secondary data. The variables in this research are financial performance from profitability ratio that includes return on asset (ROA), return on equity (ROE), net profit margin (NPM). The sample of this research consist of 13 companies with purposive sampling method that is company which become participant of Indonesian Sustainability Reporting Awards consistently three consecutive year in 2007-2011 period. Data collection of research samples can be accessed through the company website and website National Center of Sustainability Reporting and the company publishes Annual Financial Reports in 2004-2014 that can be accessed through the company website. Hypothesis testing was done by paired sample t-test technique using IBM SPSS version 20 software. The result showed that there was no difference of company performance between before and after participated in Indonesian Sustainability Reporting Awards.
\end{abstract}

Keywords : Indonesian Sustainability Reporting awards, Corporate Financial Performance, and Profitabillity Ratio. 


\section{PENDAHULUAN}

Saat ini perhatian lingkungan bisnis tidak hanya berfokus pada bagaimana perushaan mendapat keuntungan, namun juga memperhatikan bagaimana tanggung jawab sosial perusahaan. Hal ini di sebabkan oleh munculnya isu mengenai lingkungan yang menarik perhatian masyarakat di seluruh dunia. Perusahan diharapkan memiliki tanggung jawab tidak hanya pada kondisi keuangan saja. Tanggung jawab perusahaan harus berpijak pada triple bottom lines, meliputi aspek finansial (profit), aspek lingkungan (planet), dan aspek sosial (people) (Untung, 2008 dalam Firmani,

2013). Konsep bottom line ini juga di tuangkan dalam suatu bentuk pelaporan yang dikenal dengan laporan keberlanjutan atau sustainability report (Certified General Accountant association of Canada, 2005, ballou, Heitger, \& Landes dalam Widyaastuti, 2014).

Di Indonesia sendiri, telah ditetapkan aturan bagi perusahaan untuk melaporkan pelaksanaan tanggung jawab sosial dan lingkungannya dalam Pasal 66

Ayat 2 Undang-Undang No.40 / 2007 tentang Perseroan Terbatas dan aturan Bapepam-LK yang mengharuskan emiten mengungkapkan pelaksanaan kegiatan Corporate Social Responsibility (CSR) di dalam laporan tahunan perusahaan (Widyaastuti, 2014). Meskipun telah diwajibkan melalui peraturan yang dikeluarkan, sustainability reporting masih tergolong dalam tahap pengenalan di Indonesia. Maka, dalam rangka mendukung proses pengenalan sustainability reporting ini di Indonesia, diadakan Indonesian Sustainability Reporting Award (ISRA) untuk pertama kalinya pada tahun 2005. Program tahunan ini bertujuan untuk memotivasi dan memacu pelaporan kinerja keberlanjutan oleh perusahaanperusahaan yang ada di Indonesia. Sebagai penyelenggara, Institut Akuntan Manajemen Indonesia (IAMI) meyakini bahwa penganugerahan bagi pelaporan kinerja keberlanjutan sangat penting untuk meningkatkan kinerja itu sendiri. Pelaporan akan memicu benchmarking, pembelajaran, penetapan, dan pencapaian target serta membangun akuntabilitas, transparansi, dan mendorong keterlibatan seluruh pemangku kepentingan/stakeholders (NCSR,2008).

Di Indonesia sendiri, banyak penelitian yang telah dilakukan terkait dengan ISRA terutama dampaknya terhadap kinerja keuangan perusahaan. Penelitianpenelitian yang ada menunjukkan bahwa ISRA berpengaruh terhadap kinerja keuangan. Kinerja perusahaan sendiri penting bagi berbagai pihak terutama bagi investor yang telah berinvestasi dalam perusahaan. Kinerja keuangan perusahaan dengan rasio profitabilitas yang diproksikan return on asset dan return on equity pada perusahaan penerima ISRA dan non penerima ISRA menunjukkan hasil yang berbeda- beda. Penelitian Arthini \& Mimba (2016) mengungkapakan bahwa tidak ada perbedaan kinerja keuangan dari sisi ROA, ROE, dan NPM antara perusahaan pemenang ISRA dan bukan pemenang ISRA. Penelitian yang dilakukan Almilia et al. (2011) dalam Arthini \& Mimba (2015) menunjukkan hasil bahwa kinerja keuangan yang di ukur dengan ROA pada perusahaan penerima ISRA lebih tinggi dari pada perusahaan yang tidak menerima pengharagaan ISRA. Selanjutnya hasil penelitian Widiantari (2012) dalam penelitian Arthini \& Mimba (2015) menunjukkan hasil bahwa kinerja keuangan yang di ukur dengan ROA pada perusahaan penerima ISRA tidak terdapat perbedaan dibandingan perusahaan yang tidak mendapat 
penghargaan ISRA sedangkan kinerja keuangan yang diukur ROE pada perusahaan penerima ISRA lebih tinggi dari pada perusahaan penerima ISRA.

Penelitian lain dilakukan oleh Firmani (2013) menunjukkan hasil bahwa kinerja yang di ukur dengan ROA pada enam perusahaan yaitu terdapat lima perusahaan yang mengalami peningkatan setelah berpartisipasi dalam ISRA dan satu perusahan mengalami penurunan setelah berpartisipasi dalam ISRA. Sedangkan nilai ROE pada enam perusahaan menunjukkan bahwa tiga perusahaan mengalami peningkatan setelah berpartisipasi dalam ISRA dan tiga perusahaan mengalami penuruan setelah berpartisipasi dalam ISRA. Rata-rata keseluruhan nilai ROA dan ROE pada enam perusahaan menunjukkan lebih tinggi sesudah berpartisipasi dalam ISRA di banding sebelum berpartisipasi dalam ISRA. Hal ini menunjukkan bahwa ada hubungan positif antara pengungkapan pertanggungjawaban sosial terhadap kinerja keuangan perusahaan dengan rasio profitabilitas yang diproksikan return on asset dan return on equity.

Selanjutnya, penelitian lain dilakukan oleh Fitriana (2010) menjelaskan bahwa pengujian yang dilakukan untuk hipotesis dengan variabel kinerja keuangan perusahaan Rasio Profitabilitas yaitu ROI membuktikan bahwa terdapat perbedaan yang signifikan pada perusahaan sebelum dan sesudah menerima penghargaan ISRA 2007. Serta Pengujian yang dilakukan untuk hipotesis dengan variabel kinerja keuangan perusahaan Rasio Profitabilitas yaitu ROE membuktikan bahwa terdapat perbedaan yang signifikan pada perusahaan sebelum dan sesudah menerima penghargaan ISRA 2007.

Di Indonesia sendiri, penelitian yang dilakukan masih banyak berkisar pada penelitian mengenai kinerja keuangan peraih penghargaan ISRA atau pemenang ISRA. Sementara penelitian mengenai partisipan ISRA masih sedikit jumlahnya. Oleh karena itu, penulis tertarik untuk melakukan penelitian lebih lanjut untuk mengetahui apakah terdapat perbedaan kinerja keuangan perusahaan sebelum dan sesudah berpartisipasi dalam Indonesia Sustainability Reporting Award. Pada penelitian sebelumnya yang dilakukan oleh Firmani (2013) kinerja keuangan diukur dengan Return on Total Assets (ROA) dan Return on Equity (ROE) pada perusahaan yang beraprtisipasi dalam ISRA pada periode 2007-2011.

Adanya hasil penelitian yang berbeda beda tersebut, maka dalam penelitian ini peneliti tertarik dan ingin membuktikan perbedaan kinerja keuangan dengan rasio profitabilitas yang diproksikan return on asset, return on equity, dan net profit margin terhadap perusahaan yang berpartisipasi dalam ISRA pada tahun 2007-2011 dengan judul penelitian “Analisis Perbedaan Kinerja Keuangan Perusahaan Antara Sebelum dan Sesudah Berpartisipasi dalam Indonesia Sustainability Reporting Awards (ISRA)". Penelitian ini bertujuan untuk mengetahui perbedaan kinerja keuangan perusahaan antara sebelum dan sesudah menjadi partisipan Indonesia Sustainability Reporting Awards (ISRA).

\section{Kinerja Keuangan}

Kinerja keuangan menjadi yang utama, secara mayoritas para stakeholder tentu ingin tahu betul mengenai hal tersebut sebagai dasar dalam pengambilan keputusan (Sari, 
2013 dalam Natalia dan Tarigan, 2014). Kinerja keuangan perusahaan tercermin dalam laporan keuangan yang mana dapat dilihat hasil dalam tahun tertentu ataupun dijadikan perbandingan dengan tahun-tahun sebelumnya sehingga dapat dilihat perkembangan atau penurunan yang terjadi dari tahun ke tahun serta berapa selisihnya untuk mengetahui konsisten tidaknya perusahaan tersebut (Soelistyoningrum, 2011 dalam Natalia dan Tarigan,2014).

Kinerja adalah suatu usaha formal yang dilaksanakan perusahaan untuk mengevaluasi efisien dan efektivitas dari aktivitas perusahaan yang telah dilaksanakan pada periode waktu tertentu (Hanafi,2003 dalam Firmani,2013). Pengukuran kinerja merupakan analisis data serta pengendalian bagi perusahaan. Pengukuran kinerja digunakan perusahaan untuk melakukan perbaikan atas kegiatan operasionalnya agar dapat bersaing dengan perusahaan lain,serta untuk memperlihatkan kepada penanam modal maupun pelanggan atau masyarakat secaraumum bahwa perusahaan memiliki kredibilitas yang baik, bagi investor informasi mengenai kinerja perusahaan dapat digunakan untuk melihat apakah mereka akan mempertahankan investasi mereka di perusahaan tersebut atau mencari alternative lain(Munawir,2002 dalam Firmani,2013).

Menurut Meriewaty dan Setyan i(2005) dalam Firmani (2013), kinerja keuangan merupakan pengukuran prestasi perusahaan yang ditimbulkan sebagai akibat dari proses pengambilan keputusan manajemen yang kompleks dansulit, karena menyangkut efektivitas, pemanfaatan modal, efisiensi, dan rentabilitas dari kegiatan perusahaan. Pengukuran kinerja keuangan dapat dilakukan dengan penilaian analisis rasio keuangan. Analisisrasio sangat bermanfaat bagi manajemen untuk perencanaan dan pengevaluasian prestasiatau kinerja (performance) perusahaan (Munawir,2002 dalam Firmani,2013). Selanjutnya akan dibahas apa saja rasio-rasio yang akan digunakan dalam menganalisis kinerja keuangan suatu perusahaan.

\section{Rasio Keuangan}

Rasio keuangan sangat penting untuk melakukan analisa terhadap kondisi keuangan perusahaan. Analisis rasio digunakan dengan cara membandingkan suatu angka tertentu pada suatu akun terhadap angka dari akun lainnya. Analisis rasio sering digunakan oleh manajer, analisis kredit dan analisis saham. Analisis rasio bermanfaat karena membandingkan suatu angka secara relative, sehingga bisa menghindari kesalahan penafsiran pada angka mutlak yang ada di dalam laporan keuangan. Murhadi (2013) analisis rasio yang digunakan dalam analisis laporan keuangan adalah sebagai berikut :

\section{Rasio Likuiditas (Liquidity Ratio)}

Adalah rasio yang menunjukan kemampuan perusahaan dalam memenuhi liabilitas jangka pendeknya. Berikut 3 rasio yang biasa digunakan:

a. Current Ratio

Current Ratio adalah rasio yang biasa digunakan untuk mengukur kemampuanperusahaan dalam memenuhi liabilitas jangka pendek yang akan jatuh tempo dalam waktu satu tahun. 
b. Quick ratio (acid test ratio)

$$
\text { current ratio }=\frac{\text { current asset }}{\text { current liabilities }}
$$

Rasio ini lebih ketat dalam mencerminkan kemampuan perusahaan memenuhi liabilitas lancer karena unsur asset lancer yang kurang likuid seperti persediaan dan biaya dibayar dimuka dikeluarkan dari perhitungan.

$$
\text { quick ratio }=\frac{\text { current asset }- \text { (inventories }+ \text { prepayment })}{\text { current liabilities }}
$$

c. Cash ratio

Pendekatan yang lain dapat digunakan untuk mengukur kemampuan perusahaan dalam memenuhi liabilitas jangka pendek adalah rasio kas dan setara kas dalam hal ini marketable securities yang dimiliki oleh perusahaan.

$$
\text { cash ratio }=\frac{\text { cash }+ \text { marketable securities }}{\text { current liabilities }}
$$

\section{Rasio Pengelolaan Asset (Asset Management Ratio)}

Adalah rasio yang menggambarkan efektivitas perusahaan dalam pengelolaan asset dalam hal ini mengubah asset non kas menjadi asset kas.

a. Receivables turnover ratio (RTR) periode.

Rasio perputaran piutang menunjukan perputaran piutang dalam satu

$$
\mathrm{RTR}=\frac{\text { annual sales }}{\text { average receivable }}
$$

Makin tinggi RTR, mengindikasikan bahwa investasi yang ditanamkan dalam bentuk piutang adalah rendah, sebaliknya bila RTR rendah menunjukkan bahwa perusahaan terlalu banyak atau terlalu longgar dalam pemberian piutang kepada pelanggan.Penurunan rasio ini bisa disebabkan oleh beberapa hal yaitu:

i. $\quad$ Turunnnya penjualan dan naiknya piutang

ii. Turunnya piutang dan diikuiti dengan turunnya penjualan dalam jumlah yang lebih besar

iii. Naiknya penjualan diikuti dengan naiknya piutang dalam jumlah yang lebih besar

iv. Turunnya penjualan dengan piutang yang tetap

v. Naiknya piutang sedangkan penjualan tidak berubah

b. Average Collection Period (ACP)atau Days of Sales Outstanding (DSO)

Periode pengumpulan piutang mengindikasikan rata-rata lamanya piutang perusahaan yang diberikan kepada konsumennya. 


$$
\text { DSO }=\frac{360}{\text { receivable turnover }}
$$

c. Inventori Turnover Ratio (ITR)

Rasio perputaran persediaan mengindikasikan efisiensi perusahaan dalam memproses dan mengelola persediaannya.

$$
\text { ITR }=\frac{\text { cost of good sold }}{\text { average inventory }}
$$

Rasio ini menunjukan berapa kali persediaan barang dagang diganti/diputar dalam satu periode. Makin tinggi perputaran persediaan akan menunjukan makin efisien penggunaan persediaan dalam rangka mendukung penjualan perusahaan.

d. Days Of Inventory (DOI)

Umur persediaan menunjukan berapa lama persediaan tersebut tersimpan dalam perusahaan. harapan kita adalah rata-rata umur persediaan tidak terlalu lama, sehingga tidak menimbulkan biaya penyimpanan yang besar.

$$
\text { DOI }=\frac{365}{\text { inventory turnover }}
$$

e. Payable Turnover (PT)

Rasio ini mengukur penggunaan utang oleh perusahaan.

$$
\text { Payable Turnover }=\frac{\text { annual credit purchase }}{\text { average trade parable }}
$$

f. Average Payment Period (APP)

Rasio ini menunjukan rata-rata lamanya waktu yang dibutuhkan untuk pembayaran utang dagang.

$$
\begin{gathered}
A P P=\frac{365}{\text { payable turnover }} \\
\text { atau } \\
\text { aPP }=\frac{365 \text { average trade parable }}{\text { annual credit purchase }}
\end{gathered}
$$

Makin lama pembayaran utang adalah baik, namun dengan catatan utang tersebut harus tetap dibayar dengan tidak merusak reputasi kredit perusahaan.

\section{g. Total Asset Turnover (TAT0)}

Rasio ini menunjukan efektivitas perusahaan dalam menggunakan asetnya untuk menghasilkan pendapatan.

$$
\text { TATO }=\frac{\text { net sales }}{\text { total asset }}
$$




\section{Rasio Pengelolaan Utang (Debt Management Ratio)}

Rasio Pengelolaan UtangAdalah rasio yang menggambarkan kemampuan perusahaan dalam mengelola dan melunasi kewajibannya. Biasanya rasio ini dibedakan menjadi dua kelompok yakni rasio utang (leverage ratio) yang menggambarkan proporsi utang terhadap asset ataupun ekuitas dan solvency ratio adalah rasio yang menggambarkan kemampuan perusahaan untuk memenuhi kewajiban pokok maupun bunga.

Kategori yang termasuk leverage ratio adalah sebagai berikut:

a. Debt Ratio (DR)

Debt Ratio menunjukan seberapa besar total asset yang dimiliki perusahaan yang didanai oleh seluruh kreditnya.

b. Debt To Equity Ratio (DER)

$$
D R=\frac{\text { total debt }}{\text { total asset }}
$$

Rasio yang menunjukan perbandingan antara hutang dak ekuitas perusahaan.

c. Long-Term Debt To Equity (LTDE)

$$
D E R=\frac{\text { total debt }}{\text { total equity }}
$$

Menunjukan perbandingan antara utang jangka panjang terhadap ekuitas.

$$
D R=\frac{\text { total long term debt }}{\text { total equity }}
$$

Sedangkan yang termasuk solvency ratio adalah sebagai berikut:

a. Times Interst-Earned Ratio (TIER)

Adalah rasio yang menggambarkan kemampuan hasil operasional perusahaan untuk menutupi kewajiban bunga. makin rendah rasio TIER menunjukan kemampuan hasil operasioanl perusahaan untuk menutupi bunga adalah rendah.

$$
\text { TIER }=\frac{\text { earning before interest } \& \text { tax }}{\text { interest exepnce }}
$$

b. Debt Service Coverage Ratio (DSCR)

Merupakan rasio yang menggambarkan jumlah kas yang tersedi untuk memenuhi kewajiban bunga dan pokok utang termasuk di dalamnya alokasi singking fund (yaitu dana yang disisihkan tiap tahun untuk pembayaran kewajiban obligasi pasda saat jatuh tempo.

$$
D S C R=\frac{\text { net operating income }}{\text { total debt service }}
$$

c. Solvency Ratio (SR)

Mencerminkan kemampuanperusahaan untuk memenuhi kewajibannya 


$$
S R=\frac{\text { after tax net profit }+ \text { depreciation }}{\text { long term liabilities }+ \text { short term liabilities }}
$$

d. DEBT/EBITDA

Earning Before Interest, Taxes, Depreciation, and Amortization (EBITDA) mencerminkan tingkat hasil operasional riil perusahaan. DEBT/EBITDA sendiri mengukur perbandingan antara besarnya hutang terahdap kemampuan perusahaan menghasilkan labaoperasi.Semakin tinggi DEBT/EBITDA maka makin beresiko perusahaan, dimana kemampuan hasil operasional perusahaan tidak mampu mengkover utangnya.

\section{Rasio Profitabilitas (Profitability Ratio)}

Rasio ini menggambarkan kemampuan perusahaan untuk menghasilkan keuntungan.

\section{a. Gross Profit Margin (GPM)}

Rasio yang menggambarkan persentase laba kotor yang dihasilkan oleh setiap pendapatan perusahaan. Harapan makin tinggi GPM, maka akan makin baik.

$$
G P M=\frac{\text { gross profit }}{\text { revenue }}=\frac{\text { net sales }- \text { COGS }}{\text { revenue }}
$$

b. Operating Margin (OM)

Operating margin mencerminkan kemampuan manajemen mengubah aktivitasnya menjadi laba. Harapannya, makin tinggi OM, maka akan makin baik.

$$
O M=\frac{\text { operating income }}{\text { revenue }}=\frac{E B I T}{\text { revenue }}
$$

c. Net Profit Margin (NPM)

Rasio ini mencerminkan kemampuan perusahaan dalam menghasilkan laba neto dari setiap penjualannya. Harapan, makin tinggi NPM, maka akan makin baik.

$$
N P M=\frac{\text { net profit margin }}{\text { revenue }}
$$

d. Return On Equity (ROE)

ROE mencerminkan seberapa besar return yang dihasilkan bagi pemegang saham atas setiap rupiah uang yang ditanamkannya. Harapannya makin tinggi ROE, maka akan makin baik.

$$
R O E=\frac{\text { net income }}{\text { total equity }}
$$

e. Return On Assets (ROA)

ROA mencerminkan seberapa besar return yang dihasilkan atas setiap rupiah uang yang ditanamkan dalam bentuk asset. 


$$
R O A=\frac{\text { net income }}{\text { total asset }}
$$

\section{Rasio Nilai Pasar (Market Value Ratio)}

a. Earing Per Share (EPS)

Earning per share adalah pendapatan per lembar saham yang dilihat di laporan laba rugi. EPS mencerminkan pendapatan tiap lembar saham yang akan diperoleh pemegang saham, bila semua pendapatan tersebut dibagikan dalam bentuk dividen.

$$
E P S=\frac{\text { net income }}{\text { jumlah saham biasa }}
$$

b. Dividend Payout Ratio (DPR)

DPR merupakan rasio yang menggambarkan besarnya proporsi dividen yang dibagikan terhadap pendapatan bersih perusahaan.

$$
D P R=\frac{\text { dividen } / \text { share }}{\text { earnings } / \text { share }}=\frac{\text { dividend }}{\text { net income }}
$$

c. Price To Earnings Ratio (PER)

PER menggambarkan perbandingan antara harga pasar dengan pendapatan perlembar saham.

d. Dividend Yield (DY)

$$
P E R=\frac{\text { price } / \text { lembar saham }}{E P S}
$$

DY menunjukan perbandingan antara dividen yang diterima investor terhadap harga pasar saham saat ini.

$$
D Y=\frac{\text { dividend/lembar }}{\text { harga saham saat ini }}
$$

e. Price To Book Value Ratio (P/B or PBV)

Rasio ini adalah rasio yang menggambarkan perbandingan antara harga pasar saham dan nilai buku ekuitas sebagaimana yang ada di laporan posisi keuangan.

f. Price/Sales Ratio

$$
P B V=\frac{\text { harga saham per lembar }}{\text { nilai buku ekuitas per lembar }}
$$

Sales ratio adalah rasio yang membandingkan nilai kapitalisasi pasar perusahaan terhadap penjualan. Rasio ini bertujuan untuk melihat hubungan antara tingkat penjualan dan harga saham perusahaan.

$$
\begin{gathered}
\text { PSR }=\frac{\text { nilai } \text { kapitalisasi pasar }}{\text { sales }} \\
\text { atau } \\
\text { PSR }=\frac{\text { harga saham } x \text { jumlah saham beredar }}{\text { sales }}
\end{gathered}
$$

g. Price Earnings Ratio To Growth (PEG Ratio) 
Merupakan rasio harga per pendapatan (PER) dibandingkan terhadap pertumbuhan perusahaan. Analisis biasanya akan membandingkan antara PER dengan tingkat pertumbuhan yang diharapkan untuk mengidentifikasi apakah saham perusahaan tersebut mengalami undervalue atau overvalue. Secara sederhana bila PER lebih kecil dari tingkat pertumbuhan yang diharapkan maka saham tersebut dapat dikatakan mengalami undervalue. Adapun kriteria untuk melihat apakah harga saham tersebut undervalue atau overvalue dengan berdasarkan pada:

$\mathrm{PEG}<1$, harga saham tersebut undervalue

$P E G=1$, harga saham sudah pada tingkat yang wajar (fair value)

PEG $>1$, harga saham mengalami overvalue.

$$
P E G=\frac{P E R}{\text { tingkat pertumbuhan yang diharapkan }}
$$

\section{Defenisi dan Tujuan Suistanability Reporting}

Sustainability Report ialah laporan yang berisi informasi kinerja keuangan dan non keuangan yang terdiri dari informasi mengenai kegiatan perusahaan dalam aspek ekonomi,sosial dan lingkungan yang memungkin kan keberlanjutan perusahaan tersebut (Elkington,dalam Arthini dan Mimba,2016). Sustainability atau keberlanjutan ialah keseimbangan antara people, planet, profit dan yang disebut dengan konsep Triple Bottom Line. Elkington (1997) dalam Arthini dan Mimba (2016) berpendapat bahwa perusahan bertanggung jawab atas dampak positif dan dampak negatif yang dihasilkan oleh perusahaan pada aktivitas ekonomi, sosial dan lingkungan. Luke (2013) dalam Arthini dan Mimba (2016)berpendapat bahwa pengungkapan triple bottom line dapat meningkatkan transparansi mengenai dampak kegiatan ekonomi, sosial, dan lingkungan perusahaan yang kemudian akan menjadi pertimbangan dalam keputusan investasi oleh parastakeholder.

Penerapan pelaporan keberlanjutan di Indonesia didukung oleh sejumlah peraturan sebagaimana Undang Undang Nomor 25 Tahun 2007 mengenai Penanaman Modal serta Undang Undang Nomor 40 Tahun 2007m engenai Perseroan Terbatas yang menuntut investor dan perusahaan untuk menjalankan tanggungjawab sosial perusahaan. Halitu berarti adanya dukungan pemerintah dalam pengungkapan laporan berkelanjutan dalam setiap aktivitas perusahaan supaya terwujud keseimbangan antara aspek ekonomi, sosial dan lingkungan (Akis, 2012 dalam Arthini dan Mimba,2016).

Pelaksanaan pelaporan keberlanjutan mempunyai beberapa manfaat antara lain, laporan keberlanjutan bermanfaat bagi perusahaan sebagai alat pengukur untuk mencapai sasaran kerja dalam konsep Triple Bottom Line. Laporan keberlanjutan bermanfaat bagi investor sebagai alat kontrol atas pencapaian kinerja perusahaandansebagaialatpertimbanganinvestor dalammenyediakan sumber daya keuangannya terutama dalamlingkupinvestasiberkelanjutan. Laporan keberlanjutan menjadi standa runtuk mengevaluasi keseriusan komitmen perusahaan atas pembangunan berkelanjutan bagi pemangku kepentingan lain seperti media, organisasi non pemerintah, pemerintah, konsumen, akademis dan lain-lain (Soelistyoningrum,2011 dalam Arthini dan Mimba,2016). 
Arthini dan Mimba (2016) menyebutkan bahwa semakin banyak perusahaan yang mempublikasikan sustainability report dapat menjadi strategibagi perusahaan demi meningkatkan kinerja keuangannya. Hal ini didukung dengan adanya penelitian dari Reddy dan Lucus (2010) yang menunjukkan hasil bahwa sustainability reporting berpengaruh signifikan dalam menjelaskan peningkatan profitabilitas perusahaan di Australia. Pengungkapan tersebut dinilai dari aspek ekonomi, sosial, dan lingkungan.

Perusahaan yang mempublikasikan sustainability reporting dapat meningkatkan perhatian perusahaan terhadap lingkungan dan kemampuan perusahaan dalam memelihara sumber daya manusia yang bertalenta,pengelolaan kekayaan perusahaan,konsumen,serta meningkatkan kepercayaan stakeholders sehingga profit perusahaan menjadi meningkat (Adhima, 2010 dalam Arthini dan Mimba,2016).

Pengungkapan sustainability report bertujuan untuk menyiapkan tambahan informasi terkait kegiatan perusahaan dan sebagai sarana untuk memberikan sinyal bagi pemangku kepentingan tentang kepedulian perusahaan terhadap sosial dan lingkungannya. Berdasarkan teori sinyal, suatu pengumuman yang mempunyai kandungan informasi akan membuat pasarbereaksi (Zenoviadan Anca,2009). Reaksi pasar dalam pengungkapan sustainabilitas dipengaruhi oleh perspekstif stakeholder s(Matten, 2003 dalam Arthini dan Mimba,2016)

Pengungkapan sustainability report yang tepatdan sesuai keinginan pemangku kepentingan semacam sinyal yang dikirimkan oleh sisi manajemen terhadap masyarakat bahwa perusahaan mempunyai peluang yang bagus di masa depan dan menegaskan terwujudnya sustainability development (Laksmita ningrum, 2013 dalam Arthini dan Mimba,2016). Sinyal yang dinginkan dapat diterima secara positif sehingga bisa mempengaruhi kinerja keuangan perusahaan yang terlihat dalam return on asset, return on equity, serta net profit margin.

Sustainability reporting adalah sebuah alat komunikasi dimana organisasi/perusahaan dapat mengungkapkan nilai ekonomi,sosial, dan lingkungan kepada parastakeholder, dan menampilkan respon organisasi terhadap perubahan iklim, masalah-masalah sosial, serta masalah keberlanjutan lainnya.Tujuan Indonesia Sustainability Reporting Awards (ISRA), antara lain: a)Memberikan pengakuan kepada perusahaan yang melaporkan dan mempublikasikan informasi mengenai kinerja lingkungan,sosial,dan informasi keberlanjutan;b) Mendukung pelaksanaan pelaporan di bidang lingkungan, sosial, dan keberlanjutan; c)Meningkatkan akuntabilitas perusahaan dengan menekankan tanggungjawab terhadap pemangku kepentingan utama (key stakeholders); d) Meningkatkan kesadaran perusahaan terhadap transparansi dan pengungkapan(http://isra.ncsr-id.org/). 


\section{Pengaruh Sustainability Reporting Terhadap Kinerja Keuangan Perusahaan Publik Dari Sisi Profitability Ratio}

\section{Pengaruh Pengungkapan kinerja ekonomi terhadap profitabilitas}

Dengan adanya laporan berkelanjutan yang memunculkan dimensi ekonomi yang berkelanjutan dapat memberikan penjelasan mengenai dampak organisasi pada kondisi ekonomi stakeholder dan pada sistem ekonomi di tingkat lokal, nasional serta global.Aspek yang dilaporkan pada ekonomi berkelanjutan lebih pada kontribusi perusahaan terhadap besar sistem ekonomi. Sebuah penelitian oleh National Geographic dan perusahaan polling internasional Globe Scan baru-baru ini mengenai pola konsumsi berkelanjutan di 14 negara menyatakan bahwa dengan adanya kesadaran masyarakat jaman sekarang akan produk yang tidak merusak lingkungan dan peduli sosial maka muncul peluang bagi perusahaan, dengan mengungkapkan sustainability report dengan aspek ekonomi, perusahaan terdorong untuk memproduksi produk-produk yang peduli lingkungan dan sosial. Sehingga produk tersebut dapat diterima oleh masyarakat, yang akan meningkatkan image perusahaan lewat nilai perusahaan yang akan juga semakin meningkat diikuti juga dengan meningkatnya profitabilitas. Cahyandito (2009) dalam Natalia Tarigan (2014) mengungkapkan bahwa kinerja ekonomi dalam sustainability report perusahaan akan meningkatkan transparansi perusahaan yang akan meningkatkan pula kepercayaan stakeholder dan investor sehingga akan meningkatkan pula image perusahaan. Pengungkapan pendekatan manajemen dapat mencakup tiga aspek ekonomi yaitu keberadaaan pasar, dan dampak ekonomi tidak langsung.

\section{Pengaruh Pengungkapan kinerja lingkungan terhadap profitabilitas}

Dimensi lingkungan berkelanjutan adalah dampak yang dihasilkan melalui aktifitas produksi perusahaan terhadap lingkungan yang meliputi bahan yang digunakan, energi dan konsumsinya, ekosistem, tanah, udara dan air dan konsumsinya, pembuangan-emisi-pelepasan limbah (cair, padat, gas), transport.Perusahaan harus menjaga hubungan dengan stakeholdernya dengan mengakomodasi keinginan dan kebutuhan stakeholdernya (Chariri dan Ghozali, 2007).Maka dari itu perlunya diungkapkan sustainability report untuk menjawab tuntutan dari para stakeholder. Sehingga stakeholder dapat mengetahui kinerja perusahaan yang peduli akan lingkungan dan dapat memberikan respon positif dengan memberikan pendanaan bagi perusahaan yang akan digunakan untuk meningkatkan produksi dan penjualan sehingga dapat meningkatkan profitabilitas perusahaan. Nurdin dan Cahyandito (2006) juga menunjukkan adanya hubungan antara laporan kinerja lingkungan terhadap harga saham dan return saham. Hal ini memberikan penjelasan bahwa kinerja lingkungan perusahaan memberikan akibat pada kinerja finansial perusahaan yang tercermin pada tingkat return tahunan perusahaan yang meningkat yang dibandingkan dengan return industri yang tentunya akan berdampak pada image perusahaan yang tercermin melalui nilai perusahaan dimana dapat berpengaruh juga terhadap profitabilitas perusahaan. 


\section{Pengungkapan kinerja sosial berpengaruh positif terhadap profitabilitas}

Dimensi Sosial dalam sustainability report menyangkut dampak organisasi terhadap masyarakat dimana mereka beroperasi, dan menjelaskan risiko dari interaksi dengan institusi sosial lainnya yang mereka kelola.Kepedulian perusahaan dalam mengantisipasi isu-isu terkait masyarakat seperti komunitas, korupsi, kebijakan publik, anti kompetitif seperti anti-trust dan monopoli.Dimensi sosial ini dibagi dalam empat aspek, yaitu hak asasi manusia, masyarakat, tanggungjawab produk dan tenaga kerja dan pekerjaan layak.Menurut Guthrie dan Parker (1989, dalam Chariri, 2008) menyatakan bahwa dengan melakukan praktik pengungkapan kinerja sosial adalah untuk tujuan memperoleh legitimasi sebagai respon atas tekanan publik. Dengan adanya penerimaan dari masyarakat (legitimasi) maka diharapkan akan meningkatkan nilai perusahaan sehingga akan meningkatkan image perusahaan dan mempengaruhi penjualan sehingga dapat meningkatkan laba perusahaan (Soelistyoningrum, 2011 dalam Natalia dan Tarigan, 2014).

\section{METODE PENELITIAN}

Desain penelitian ini adalah kuantitatif dengan hipotesis yang bertujuan untuk menganalisis perbedaan kinerja keuangan sebelum dan sesudah berpartisipasi dalam ISRA. Variabel yang diukur dalam penelitian ini adalah variable yang member gambaran tentang kinerja keuangan perusahaan. Penilaian kinerja keuangan perusahaan dapat dilakukan dengan membuat analisis terhadap laporan keuangan perusahaan yang bersangkutan. Analisis laporan keuangan dapat dilakukan dengan menggunakan ukuran tertentu yaitu dengan rasio keuangan. Dalam penelitian ini kinerja keuangan perusahaan akan diukur melalui rasio profitabilitas, terdiri dari return onasset, return onequity,dan net profit margin yang mengacu pada peneliti sebelumnya yang dilakukan oleh Firmani (2013). Nilai return onasset, return onequity, dan net profit margin dapat diperoleh dari laporan keuangan yang sudah disediakan oleh perusahaan, jika tidak tersedia dalam laporan keuangan perusahaan maka dapat dilakukan dengan perhitungan standar, yakni sebagai berikut:

\section{Operating Return on Asset (ROA)}

ROA diukur sebagai rasio laba operasi terhadap total asset. Tingkat pengembalian operasi terhadap asset mencerminkan suatu pengukuran efisiensi dalam pengggunaan asset. Hal ini mencerminkan seberapa besar return yang dihasilkan atas setiap rupiah uang yang ditanamkan dalam bentuk asset.

$$
\mathrm{ROA}=\frac{\text { Laba Bersih }}{\text { Total aktiva }}
$$

\section{Return on Equity (ROE)}

ROE mencerminkan seberapa besar return yang dihasilkan bagi pemegang saham atas setiap rupiah uang yang ditanamkannya. Harapannya makin tinggi ROE, maka akan makin baik.

$$
\mathrm{ROE}=\frac{\text { net income }}{\text { total equity }}
$$




\section{Net Profit Margin (NPM)}

Rasio ini mencerminkan kemampuan perusahaan dalam menghasilkan laba neto dari setiap penjualannya. Harapan, makin tinggi NPM, maka akan makin baik.

$$
\mathrm{NPM}=\frac{\text { net profit margin }}{\text { revenue }}
$$

Data yang digunakan dalam penelitian ini adalah data sekunder. Data diperoleh dari Website ISRA dan Website perusahaan-perusahaan yang menjadi partisipan dalam Indonesia Sustainability Reporting Awards (ISRA) pada tahun 20072011. Data dalam penelitian ini bersumber dari data sekunder yang bersumber dari pihak eksternal dalam bentuk laporan keuangan berupa neraca dan laporan laba rugi perusahaan yang menjadi partisipan dalam event Indonesia Sustainability Reporting Award (ISRA) 2007-2011. Laporan keuangan tahun buku 2004 sampai dengan 2014 digunakan untuk menghitung perubahan rasio keuangan.

Populasi yang digunakan dalam penelitian ini adalah perusahaan yang berpartisipasi dalam Indonesia Sustainability Reporting Awards (ISRA). Sedangkan untuk sampel penelitian adalah perusahaan yang berpartisipasi dalam Indonesia Sustainability Reporting Awards (ISRA) secara konsisten selama tiga tahun berturutturutpada tahun 2007-2011.Penelitian ini menggunakan metode purposive sampling, yaitu teknik pengambilan sampel dengan pertimbangan tertentu (Sugiyono,2014). Tujuan yang di maksud agar semua sampelyang diambil dapat mewakili populasi, dimana sample harus memenuhi kriteria tertentu. Kriteria sampel dalam penelitian ini adalah sebagai berikut : a) Data pengumpulan perusahaan yang menjadi partisipan ISRA secara konsisten selama tiga tahun berturut-turut pada tahun 20072011. Cara pengumpulanperusahaan pada penelitian ini merujuk pada penelitian yang dilakukan oleh Ikhsan (2011) ; b) Data tersebut diperoleh dari publikasi yang diakses dari website http://www.ncsr-id.org ; c) Perusahaan menerbitkan laporan tahunan selama periode 2004-2014; d) Perusahaan telah mempublikasikan laporan keuangan tahun yang berakhir pada tanggal 31 Desember 2004-2014; e) Laporan tahunan dapat diakses melalui website perusahaan ; f) Perusahaan memiliki data yang terkait dengan variabel dalam penelitian ini.

Dalam penelitian ini akan dilakukan dengan pendekatan kuantitatif dengan alat statistik deskriptif dan pengujian hipotesis. Statistik deskriptif ini digunakan untuk memberikan deskripsi mengenai variabel-variabel yang akan diteliti yaitu Profitability Ratio (Return on Asset,Return on Equity, dan Net Profit Margin).Hasil analisis deskriptif meliputi nilai rata-rata, nilai minimum, nilai maximum dan standar deviasi yang berguna untuk mendukung hasil interpretasi teknik lain. Peneliti menggunakan data perubahan rasio 3 tahun sebelum dengan 3 tahun sesudah berpartisipasi dalam ISRA. Selanjutnya Pengujian hipotesis penelitian ini dilakukan dengan menggunakan uji t beda rata-rata untuk sampel berpasangan.

\section{HASIL DAN PEMBAHASAN}

Populasi penelitian yang digunakan dalam penelitian ini adalah perusahaanperusahaan yang menjadi partisipan Indonesian Sustainability Reporting Awards. Dikarenakan sampel yang digunakan dalam penelitian ini harus memiliki kriteria yaitu perusahaan yang terdaftar menjadi partisipan ISRA secara konsisten selama 3 tahun bertutut-turut pada 2007-2011. Alasan menggunakan jendela penelitian (event 
window) yang dilakukan yakni tiga tahun sebelum dan tiga tahun sesudah berpartisipasi dalam ISRA, agar dapatmenggambarkan kinerja perusahaan sebelum dan sesudah berpartisiapsi dalam ISRA.Dan juga penggunaan data di mulaidari tahun 2007-2011agar dapat memperoleh sampel yang cukup.

Berdasarkan data dari website ISRA jumlah perusahaanyang terdaftar menjadi partisipan ISRA selama periode 2007-2011 berjumlah 74 perusahaan. Keseluruhan data tersebut kemudian diambil sesuai kriteria yang telah ditentukan berdasarkan metode purposive sampling sehingga perusahaan yang dapat dijadikan sampel hanya sebanyak 13 perusahaan. Adapun tahapan proses eliminasi pemilihan sampel berdasarkan kriteria-kriteria tertentu ditunjukkan dalam tabel berikut ini :

Tabel 1

Ringkasan Pemilihan Sampel

\begin{tabular}{|l|c|}
\hline \multicolumn{1}{|c|}{ Kriteria Sampel } & Jumlah \\
\hline Jumlah perusahaan partisipan ISRA 2007-2011 & 74 \\
\hline Perusahaan tidak konsistenberpartisipasi Isra selama 3 tahun bertutut-turut & $(58)$ \\
\hline Perusahaan yang tidak lengkap laporan keuangannya & $(3)$ \\
\hline Jumlah sampel & 13 \\
\hline
\end{tabular}

Sumber: Data sekunder yang diolah, 2016

Berdasarkan observasi penelitian, dari seluruh perusahaan di Indonesia yang mempublikasikan Sustainability Reporting terdapat 74 perusahaan yang terdaftar, melaporkan dan mempublikasikan Sustainability Reporting pada National Centre for Sustainability Reporting. Namun hanya 16 dari 74 perusahaan yang berpartisipasi dalam ISRA secara konsisten (3 tahun berturut-turut) pada tahun 2007-2011. Dan diantara 16 perusahaan tersebut, 3 laporan keuangan perusahaan tidak dapat diakses secara lengkap, sehingga tidak bisa dijadikan sebagai sampel penelitian.Akhirnya hasil pengumpulan data ini didapat 13perusahaan yang bisa dijadikan sampel,diantaranya yaitu : 1) PT Pertamina (Persero) ; 2) PT Bukit Asam (persero) TBK ; 3) PT United Traktor TBK ; 4) PT Antam (persero) TBK ; 5) PT Bank CIMB Niaga TBK ; 6) PT Perusahaan Gas Negara ; 7) PT Indonesia Power ; 8) PT Telkom Indonesia TBK ; 9) PT Astra International TBK ; 10) PT Bank Mandiri TBK ; 11) Jasa Marga ; 12) PT Bakrie Sumatra Plantation TBK ; 13) PT Indosat.

Data yang digunakan dalam penelitian ini adalah data yang diperoleh dari (www.isra.ncsr-id.org).Data yang telah diperoleh kemudian diolah dengan menggunakan bantuan program SPSS versi 20.0. Uji hipotesis yang digunakan dalam penelitian ini adalah uji beda t untuk sampel berpasangan (paired-samples $t$ test). Pengujian hipotesis dilakukan dengan menggunakan tingkat signifikansi $(\alpha)$ yang masih dapat ditoleransi sebesar 5\% untuk uji pada satu sisi. Analisis uji hipotesis dilakukan pada satu sisi karena untuk mengamati adanya peningkatan atau penurunan yang terjadi pada variabel yang diteliti. Analisis data disajikan berdasarkan rasio profitabilitas menggunakan pengujian hipotesis dengan rentang waktu yang dilakukan untuk satu tahun sebelum ISRA dan dua tahun setelah ISRA. Analisis Deskriptif digunakan untuk memberikan gambaran atau deskripsi atas variabel penelitian. Pengukuran yang digunakan dalam penelitian ini adalah mean, 
standar deviasi, nilai minimum, dan nilai maximum. Tabel 2 Menunjukan statistik deskriptif masing-masing variabel penelitian.

Pada tabel 2 menunjukkan stastistik deskriptif variabel-variabel penelitian pada perusahaan sebelum dan sesudah menjadi partisipan ISRA. Komponen variabel dari rasio keuangan yakni rasio profitabilitas menunjukkan nilai rata-rata ROA sebelum beraprtisipasi dalam ISRA sebesar 0.0745lebih mendekati nilai terendah sebesar 0,01sehingga ROA pada perusahaan sebelum menjadi partisipan ISRA dapat dikatakan rendah. Sedangkan sesudah menjadi partisipan ISRA menunjukkan nilai rata-rata ROA sebesar 0.0967 lebih menedekati nilai terendah sebesar -0.15 sehingga ROA pada perusahaan sebelum menjadi partisipan ISRA juga dapat dikatakan rendah. Akan tetapi, hal ini menggambarkan bahwa ROA yang dihasilkan oleh perusahaan setelah berpartisipasi dalam ISRA mengalami peningkatan dari tingkat efisien aset yang ada di perusahaan dalam menghasilkan laba operasi, hal ini bisa dilihat dari nilai standar deviasi sebleum berpartisipasi dalam ISRA sebesar 0.06071 dan meningkat setelah berpartisipasi dalam ISRA sebesar 0.10168. Nilai ROA tertinggi perusahaan sebelum berpartisipasi dalam ISRA adalah 0,23 yaitu PT Antam (persero) TBKpada tahun 2006. Sementara ROA terendah pada perusahaan sebelum beraprtisipasi ISRA adalah 0,005yaitu ROA dari PT Bank Mandiri TBKpada tahun 2005. Sedangkan pada perusahaan setelah berpartisipasi dalam ISRA yang memiliki ROA tertinggi yakni PT Bukit Asam (persero) TBK pada tahun 2009 sebesar 0,34, dan ROA terendah yakni PT Bakrie Sumatra Plantation TBK pada tahun 2013 sebesar -0,15.

ROE pada perusahaan sebelum berartisipasi dalam ISRA memiliki Nilai ratarata ROE sebesar 0.2033 lebih mendekati nilai terendah sebesar 0 sehingga ROE pada perusahaan sebelum menjadi partisipan ISRA dapat dikatakan rendah. Adapun nilai rata-rata ROE pada perusahaan sesudah menjadi partisipan ISRA adalah 0.2044 lebih mendekati mendekati nilai terendah sebesar -0,57 sehingga ROE pada perusahaan sesudah menjadi partisipan ISRA juga dapat dikatakan rendah. Meskipun demikian, hal ini menunjukkan bahwa telah terajadi peningkatan ROE setelah berpartisipasi dalam ISRA. Nilai rata-rata ROE baik sebelum dan sesudah berpartisipasi dalam ISRA dari 13 observasi menunjukkan angka positif, yang mengindikasikan bahwa secara umum kemampuan perusahaan menghasilkan laba pada nilai buku investasi pemegang saham juga baik. Nilai tertinggi ROE sebelum ISRA terdapat pada PT Antam (persero) TBK pada tahun 2006 sebesar 0,34, sedangkan nilai terendah ROE sebelum ISRA terdapat pada PT Indonesia Powersebesar 0,022 pada tahun 2009.Adapun setelah berpartisipasi dalam ISRA nilai ROE tertinggi sebesar 0.61 pada PT perusahaan Gas Negara tahun 2012.dan ROE terendah padaPT Bakrie Sumatra Plantation TBK pada tahun 2013 sebesar -0,57.

Net Profit Margin (NPM) sebelum berpartisipasi dalam ISRA memiliki rata-rata sebesar 0.1199 lebih mendekati nilai minimum sebesar 0,01 sehingga ROE pada perusahaan sebelum menjadi partisipan ISRA dapat dikatakan rendah. Tabel diatas menunjukkan bahwa telah terjadi penurunan NPM setelah berpartisipasi dalam ISRA.Hal tersebut dapat terlihat dari nilai rata-rata NPM sebesar 0.0913 setelah berpartisipasi dalam ISRA.Rasio NPM ini digunakan untuk melihat kemampuan perusahaan dalam menghasilkan laba neto dari setiap penjualannya. Harapan, makin tinggi NPM, maka akan semakin baik kinerja perusahaan.Ditinjau dari tabel kinerja dari perusahaan memiliki tingkatan nilai tertinggi dari NPM sebelum berpartisipasi dalam ISRA adalah 0,283PT Antam (persero) TBKdi tahun 2004dan terendah milik PT Indonesia Powerdi tahun 2008 sebesar 0,0279. Sedangkan untuk nilai tertinggi 
dari NPM sesudah berpartisipasi dalam ISRA adalah 0.35 milik PT perusahaan Gas Negaradi tahun 2012 dan terendah -1,33 yakni milik PT Bakrie Sumatra Plantation TBK pada tahun 2013.

Tabel 2

Hasil Analisis Statistik Deskriptif

\begin{tabular}{|c|c|c|c|c|c|}
\hline KET & $\mathrm{N}$ & Minimum & Maximum & Mean & Std. Deviation \\
\hline ROA_SEBELUM & 39 & 0.01 & 0.23 & 0.0745 & 0.06071 \\
ROA_SESUDAH & 39 & -0.15 & 0.34 & 0.0967 & 0.10168 \\
ROE_SEBELUM & 39 & 0 & 1.13 & 0.2033 & 0.1915 \\
ROE_SESUDAH & 39 & -0.57 & 0.61 & 0.2044 & 0.19385 \\
NPM_SEBELUM & 39 & 0.01 & 0.35 & 0.1199 & 0.08153 \\
NPM_SESUDAH & 39 & -1.33 & 0.35 & 0.0913 & 0.2675 \\
\hline
\end{tabular}

Sumber : Data sekunder yang diolah, 2016

Penelitian ini dilakukan untuk menganalisis perbedaan rasio keuangan yang dihitung dengan menggunakan rasio profitabilitas yang diproksikan dengan ROA, ROE, dan NPM pada perusahaan sebelum dan sesudah berpartisipasi dalam ISRA. Pengujian hipotesis ini dilakukan dengan membandingkan rasio-rasio menggunakan program SPSS Versi 20. Variabel ROA, ROE, dan NPM menggunakan uji T-test untuk sampel berapasangan (Paired Sample T Statistic). Pengujian ini dilakukan dengan membandingkan nilai signifikansi t yang ditunjukkan oleh Sig dari t pada tabel dengan tingkat signifikansi yang diambil, dalam hal ini 0,05. Jika nilai Sig.dari t $<0,05$ maka terdapat perbedaan yang signifikaan terhadap kinerja keuangan perusahaan sebelum dan sesudah berpartisipasi dalam ISRA.

\section{Pengujian H1}

Pengujian hipotesis $\mathrm{H} 1$ dilakukan untuk mengetahui apakah terdapat perbedaan ROA pada periode sebelum dan sesudah berpartisipasi dalam ISRA.ROA mencerminkan seberapa besar return yang dihasilkan atas setiap rupiah uang yang ditanamkan dalam bentuk asset.Semakin besar nilai ROA atau Return on Assets maka kinerja perusahaan makin baik. Meningkatkan nilai ROA, dapat dilakukan dengan meningkatkan margin atau mengurangi biaya serta dapat meningkatkan penjualan pasar produk-produk dengan profit margin tinggi, serta perusahaan dapat meningkatkan frekuensi penjualan yang berpengaruh terhadap perputaran persediaan (inventory turnover). Hal tersebut meningkatkan laba perusahaan dan mempengaruhi naik turunnya ROA perusahaan.Hasil uji t atas ROA pada perusahaan sebelum ISRA dan setelah ISRA memberikan output seperti tampak pada Tabel 3 dan Tabel 4.

Pada Tabel 3 ditunjukkan ringkasan statistik untuk nilai rata-rata (mean) dan nilai standard deviasi dari kinerja ROA yang diteliti melalui sampel. Nilai mean untuk 3 tahun sebelum berpartisipasi dalam ISRA (ROA) sebesar 0.0745, dan 3 tahun sesudah berpartisipasi dalam ISRA (ROA) sebesar 0.0967. Sedangkan nilai standard deviasi untuk 3 tahun sebelum berpartisipasi dalam ISRA (ROA) sebesar 0.06071, dan 3 tahun setelah berpartisipasi dalam ISRA (ROA) sebesar 0,10168. Sebagaimana 
terlihat ROA mengalami penurunan setelahberpartisipasi dalam ISRA. Hal ini menunjukkan secara rata-rata adanya peningkatan kinerja perusahaan dalam mengoptimalkan aktiva perusahaan untuk menghasilkan laba. Karena ROA yang tinggi menyatakan bahwa perusahaan mampu mengolah aktiva secara efisien untuk menghasilkan laba. Sebaliknya ROA yang rendah menyatakan aktiva yang terdapat didalam perusahaan belum dikelola secara efisien untuk menghasilkan laba.

Tabel 3

Hasil uji rata-rata dan standar deviasi kinerja (Return On Asset) Sebelum dan Sesudah berpartisipasi dalam ISRA

Paired Samples Statistics

\begin{tabular}{|c|c|c|c|c|c|}
\hline & & Mean & N & Std. Deviation & Std. Error Mean \\
\hline \multirow{2}{*}{ ROA } & SEBELUM & 0.0745 & 39 & 0.06071 & 0.00972 \\
& SESUDAH & 0.0967 & 39 & 0.10168 & 0.01628 \\
\hline
\end{tabular}

Sumber : Data sekunder yang diolah, 2016

Tabel 4 menunjukkan hasil uji t untuk sampel berpasangan (paired samples test). Berdasarkan tabel 4, dilihat dari nilai sig $>\alpha(0,124>0.05)$, artinya bahwa nilai sig lebih besar dibandingan dengan derajat kesalahan sehingga $\mathrm{H} 1$ ditolak dan Ho diterima.Disimpulkan bahwa kinerja keuangan perusahaan sebelum dan sesudahberpartisipasi dalam ISRA tidak adaperbedaan secara signifikan. Hal ini konsisten dengan penelitianyang dilakukan Dewi dan Sudana (2015) memperoleh hasil bahwa perusahaan yang mengungkapkan sustainability reporting akan mengalami peningkatan pada Return On Asset ketika sustainability reporting dipublikasikan, sedangkan setelah tahun dipublikasikan tidak ada pengaruh pada Return On Asset perusahaan. Hal ini juga didukung oleh penelitian Arthini dan Mimba (2016) menyatakan bahwa tidak terdapat perbedaan kinerja keuangan dari sisi ROA antara perusahaan pemenang ISRA dan perusahaan bukan pemenang ISRA.

Tabel 4

\section{Hasil Uji Beda T Rasio Profitabilitas (Return On Asset) Sebelum dan Sesudah berpartisipasi dalam ISRA}

Paired Samples Test

\begin{tabular}{|c|c|c|c|c|c|c|c|c|c|}
\hline & & \multicolumn{5}{|c|}{ Paired Differences } & \multirow{3}{*}{$\mathrm{t}$} & \multirow{3}{*}{$d f$} & \multirow{3}{*}{$\begin{array}{l}\text { Sig. (2- } \\
\text { tailed) }\end{array}$} \\
\hline & & \multirow[t]{2}{*}{ Mean } & \multirow[t]{2}{*}{$\begin{array}{c}\text { Std. } \\
\text { Deviation }\end{array}$} & \multirow[t]{2}{*}{$\begin{array}{l}\text { Std. Error } \\
\text { Mean }\end{array}$} & \multicolumn{2}{|c|}{$\begin{array}{l}95 \% \text { Confidence } \\
\text { Interval of the } \\
\text { Difference }\end{array}$} & & & \\
\hline & & & & & Lower & Upper & & & \\
\hline ROA & $\begin{array}{l}\text { SEBELUM - } \\
\text { SESUDAH }\end{array}$ & -0.0222 & 0.09 & 0.01412 & -0.05079 & 0.0064 & -1.573 & 38 & 0.124 \\
\hline
\end{tabular}

Sumber : Data sekunder yang diolah, 2016 


\section{Pengujian $\mathrm{H} 2$}

Pengujian hipotesis $\mathrm{H} 2$ dilakukan untuk mengetahui apakah terdapat perbedaan ROE pada periode sebelum dan sesudah berpartisipasi dalam ISRA. Rasio ini berguna untuk mengukur seberapa besar return yang dihasilkan bagi pemegang saham atas setiap rupiah uang yang ditanamkannya.Hasil uji $t$ atas ROE pada perusahaan sebelum ISRA dan setelah ISRA memberikan output seperti tampak pada Tabel 5 dan Tabel 6.

Pada Tabel 5 terlihat untuk nilai rata-rata (mean) dari kinerja rasio ROE yang diteliti melalui sampel 3 tahun sebelum berpartisipasi dalam ISRA sebesar 0.2062dan 3 tahun sesudah berpartisipasi dalam ISRA sebesar 0.2044. Terdapat penurunan kinerja ROEsesudah berpartisipasi dalam ISRA. Jika dilihat dari nilai standard deviasi sebelum berpartisipasi dalam ISRA yang rendah, sedangkan standard deviasi sesudah berpartisipasi dalam ISRA terlihat tinggi yang menunjukkan bahwa tingkat return atas penanaman modal dari periode sebelumnya mengalami peningkatan. Karena ROE mencerminkan seberapa besar return yang dihasilkan bagi pemegang saham atas setiap rupiah uang yang ditanamkannya.

Tabel 5

Hasil uji rata-rata dan standar deviasi kinerja (Return On Equity) Sebelum dan Sesudah berpartisipasi dalam ISRA

Paired Samples Statistics

\begin{tabular}{|c|c|c|c|c|c|}
\hline & & Mean & $\mathrm{N}$ & Std. Deviation & Std. Error Mean \\
\hline \multirow{2}{*}{ ROE } & SEBELUM & 0.2062 & 39 & 0.19311 & 0.03092 \\
\hline & SESUDAH & 0.2044 & 39 & 0.19385 & 0.03104 \\
\hline
\end{tabular}

Sumber : Data sekunder yang diolah, 2016

Berdasarkan tabel 6 uji T yang telah diolah terlihat nilai sig. untuk variabel ROE terlihat nilai signifikansi sebesar 0,967nilai tersebut lebih besar dari 0,05 yang berartiH2ditolak dan Ho diteima sehingga dapatdikatakan bahwa tidak ada perbedaan yang signifikan antara perusahaan sebelum dan sesudah beraprtisipasi dalam ISRA. Harapannya makin tinggi ROE, maka akan semakin baik kinerja keuangan perusahaan.Hasil uji ini diperkuat oleh hasil penelitian Arthini dan Mimba (2016) menyatakan bahwa tidak terdapat perbedaan kinerja keuangan dari sisi ROE antara perusahaan pemenang ISRA dan perusahaan bukan pemenang ISRA. 
Tabel 6

Hasil Uji Beda T Rasio Profitabilitas (Return On Equity) Sebelum dan Sesudah berpartisipasi dalam ISRA

Paired Samples Test

\begin{tabular}{|c|c|c|c|c|c|c|c|c|c|}
\hline & & \multicolumn{5}{|c|}{ Paired Differences } & \multirow{3}{*}{$t$} & \multirow{3}{*}{$d f$} & \multirow{3}{*}{$\begin{array}{l}\text { Sig. } \\
(2- \\
\text { tailed })\end{array}$} \\
\hline & & \multirow[t]{2}{*}{ Mean } & \multirow[t]{2}{*}{$\begin{array}{c}\text { Std. } \\
\text { Deviation }\end{array}$} & \multirow[t]{2}{*}{$\begin{array}{l}\text { Std. Error } \\
\text { Mean }\end{array}$} & \multicolumn{2}{|c|}{$\begin{array}{l}95 \% \text { Confidence } \\
\text { Interval of the } \\
\text { Difference }\end{array}$} & & & \\
\hline & & & & & Lower & Upper & & & \\
\hline ROE & $\begin{array}{l}\text { SEBELUM } \\
- \\
\text { SESUDAH }\end{array}$ & 0.0018 & 0.27 & 0.04282 & -0.08488 & 0.08847 & 0.042 & 38 & 0.967 \\
\hline
\end{tabular}

Sumber : Data sekunder yang diolah, 2016

\section{Pengujian $\mathrm{H}_{3}$}

Pengujian hipotesis H3 dilakukan untuk mengetahui apakah terdapat perbedaan NPM pada periode sebelum dan sesudah berpartisipasi dalam ISRA.Rasio Net Profit Margin ini mencerminkan kemampuan perusahaan dalam menghasilkan laba neto dari setiap penjualannya. Harapannya, semakin tinggi NPM, maka akan semakin baik kinerja perusahaan. Semakin tinggi nilai NPM menandakan bahwa perusahaan tersebut semakin efisien operasionalnya. Perusahaan dapat menekan biaya-biaya yang tidak perlu, sehingga perusahaan mampu memaksimalkan laba bersih yang didapatkan.Namun begitu juga sebaliknya, semakin rendah nilai NPM menandakan bahwa perusahaan tersebut belum efisien operasionalnya. Perusahaan perusahaan sebaiknya menekan biaya-biaya yang tidak perlu, sehingga perusahaan mampu memaksimalkan laba bersih yang didapatkan.Hasil uji t atas NPM pada perusahaan sebelum ISRA dan setelah ISRA memberikan output seperti tampak pada Tabel 7 dan Tabel 8.

Pada Tabel 7 ditunjukkan ringkasan statistik untuk nilai rata-rata (mean) dan nilai standard deviasi dari kinerja NPM yang diteliti melalui sampel. Nilai mean untuk 3 tahun sebelum berpartisipasi dalam ISRA (NPM) sebesar 0.1199dan 3 tahun sesudah berpartisipasi dalam ISRA (NPM) sebesar 0.0913. Sedangkan nilai standard deviasi untuk 3 tahun sebelum berpartisipasi dalam ISRA (NPM) sebesar 0.08153, dan 3 tahun sesudah berpartisipasi dalam ISRA (NPM) sebesar 0.2675. Kemudian untuk nilai standard deviasi NPM yang naik setelah beraprtisipasi dalam ISRA menunjukkantingginya laba neto dari setiap penjualan. 
Tabel 7

Hasil uji rata-rata dan standar deviasi kinerja (Net Profit Margin) Sebelum dan Sesudah berpartisipasi dalam ISRA

\begin{tabular}{|c|c|c|c|c|c|}
\hline \multicolumn{6}{|c|}{ Paired Samples Statistics } \\
\hline & & Mean & $\mathrm{N}$ & Std. Deviation & Std. Error Mean \\
\hline \multirow[t]{2}{*}{ NPM } & SEBELUM & 0.1199 & 39 & 0.08153 & 0.01306 \\
\hline & SESUDAH & 0.0913 & 39 & 0.2675 & 0.04284 \\
\hline
\end{tabular}

Sumber : Data sekunder yang diolah, 2016

Berdasarkan tabel 8, diketahui bahwa nilai sig untuk kinerja NPM 3 tahun sebelum berpartisipasi dalam ISRA dan 3 tahun sesudah berpartisipasi dalam ISRA adalah 0,503, dengan derajat kesalahan yang sudah ditetapkan yaitu sebesar 0,05. Sehingga dapat dilihat $0,503>0,05$ artinya bahwa nilai sig lebih besar dibandingan dengan derajat kesalahan sehingga $\mathrm{H}_{3}$ ditolak dan $\mathrm{H}_{0}$ diterima dan disimpulkan bahwa kinerja keuangan perusahaan sebelum berpartisipasi dalam ISRA tidak terdapat perbedaan kinerja secara signifikan setelah berpartisipasi dalam ISRA. Hasil uji ini didukung oleh hasil penelitian Arthini dan Mimba (2016) menyatakan bahwa tidak terdapat perbedaan kinerja keuangan dari sisi NPM antara perusahaan pemenang ISRA dan perusahaan bukan pemenang ISRA.

Tabel 8

Hasil Uji Beda T Rasio Profitabilitas (Net Profit Margin) Sebelum dan Sesudah berpartisipasi dalam ISRA

Paired Samples Test

\begin{tabular}{|c|c|c|c|c|c|c|c|c|c|}
\hline & \multicolumn{5}{|c|}{ Paired Differences } & \multirow{3}{*}{$t$} & \multirow{3}{*}{$d f$} & \multirow{3}{*}{$\begin{array}{l}\text { Sig. } \\
(2- \\
\text { tailed })\end{array}$} \\
\hline & & \multirow[t]{2}{*}{ Mean } & \multirow[t]{2}{*}{$\begin{array}{c}\text { Std. } \\
\text { Deviation }\end{array}$} & \multirow{2}{*}{$\begin{array}{l}\text { Std. } \\
\text { Error } \\
\text { Mean }\end{array}$} & \multicolumn{2}{|c|}{$\begin{array}{l}95 \% \text { Confidence } \\
\text { Interval of the } \\
\text { Difference }\end{array}$} & & & \\
\hline & & & & & Lower & Upper & & & \\
\hline NPM & $\begin{array}{l}\text { SEBELUM - } \\
\text { SESUDAH }\end{array}$ & 0.02867 & 0.26 & 0.04238 & -0.05713 & 0.1145 & 0.676 & 38 & 0.503 \\
\hline
\end{tabular}

Sumber : Data sekunder yang diolah, 2016

Berdasarkan pada analisis data yang telah dilakukan, maka dapat dilakukan pembahasan hipotesis sebagai berikut:

Hasil analisis data kinerja keuangan dengan sampel seluruh perusahaan 3 tahun sebelum berpartisipasi dalam ISRA dan 3 tahun sesudah berpartisipasi dalam ISRA ditunjukkan melalui tabel 9. Berdasarkan tabel dapat dilihat bahwa seluruh rasio keuangan yang digunakan untuk mengukur kinerja perusahaan rata-rata tidak memiliki perbedaan yang signifikan sebelum dan sesudah berpartisipasi dalam ISRA.Hal ini dikarenakan untuk kasus di Indonesia berpartisipasi dalam ISRA belum menjadi informasi yang penting bagi stakeholder. Hal tersebut menunjukkan bahwa 
terdapat banyak informasi lain selain menjadi partisipan ISRA, yang lebih mempengaruhi perhatian para stakeholder.

Tabel 9

Perkembangan kinerja perusahaan sebelum dan sesudah berpartisipasi dalam Indonesia Sustainability Reporting Awards (ISRA)

\begin{tabular}{ccc} 
RASIO & \multicolumn{2}{c}{ MEAN } \\
& SEBELUM & SESUDAH \\
\hline ROA & 0.0745 & 0,0967 \\
ROE & 0.2062 & 0.2044 \\
NPM & 0,1199 & 0,0913 \\
\hline
\end{tabular}

Sumber : Data sekunder yang diolah, 2016

Berikut tabel ringkasan hasil uji t untuk 3 tahun sebelum dan 3 tahun sesudah berpartisipasi dalam ISRA:

Tabel 10

Ringkasan hasil uji t untuk 3 tahun sebelum berpartisipasi dalam ISRA dan 3 tahun sesudah berpartisipasi dalam ISRA untuk seluruh sampel

\begin{tabular}{|c|l|c|c|}
\hline \multicolumn{2}{|l|}{} & Sig. (2-tailed) & Ha \\
\hline Pair 1 & $\begin{array}{l}\text { ROA_Sebelum - } \\
\text { ROA_Sesudah }\end{array}$ & 0,124 & Ditolak \\
\hline Pair 2 & $\begin{array}{l}\text { ROE_Sebelum - } \\
\text { ROE_Sesudah }\end{array}$ & 0,967 & Ditolak \\
\hline Pair 3 & $\begin{array}{l}\text { NPM_Sebelum - } \\
\text { NPM_Sesudah }\end{array}$ & 0,503 & Ditolak \\
\hline
\end{tabular}

Pada tabel 10.dijelaskan lebih lanjut bahwa hasil penelitian ini menunjukkan bahwa tidak ada perbedaan kinerja keuangan dari sisi ROA,ROE, dan NPM antara sebelum dan sesudah berpartisipasi dalam ISRA sehingga hipotesis ditolak.Hasil penelitian ini mendukung penelitian Arthini dan Mimba (2016) menyatakan bahwa tidak terdapat perbedaan kinerja keuangan dari sisi ROA,ROE,dan NPM antara perusahaan pemenang ISRA dan perusahaan bukan pemenang ISRA. Penelitian Sanjaya (2007) menunjukkan bahwa tidak terdapat perbedaan yang signifikan antara tingkat profitabailitas perusahaan sebelum pelaksanaan sustainability Reportingdengan sesudah pelaksanaan sustainability reporting.Selanjutya hasil 
penelitian Wijaya (2012) yang menyatakan bahwa profitabilitas tidak berpengaruh secara signifikan terhadap pengungkapan tanggung jawab sosial.Nofianto dan Agustina (2014) dalam penelitiannya juga mengungkapkan bahwa sustainability report tidak berpengaruh terhadap kinerja keuangan.

Penelitian ini tidak konsisten dengan penelitian Kusuma (2013) yang menyatakan terdapat perbedaan kinerja keuangan yang diproksikan dengan Return On Asset antara 5 periode sebelum dan 5 periode sesudah pengungkapan CSR pada perusahaan peraih penghargaan ISRA periode 2011. Selanjutnya hasil penelitian Firmani (2013) menyatakan bahwa berdasarkan perhitungan ROA dan ROE terdapat perbedaan kinerja keuangan antara sebelum dan sesudah berpartisipasi dalam ISRA 2007-2011. Penelitian Fitriana (2007) juga menyatakan bahwa terdapat perbedaan kinerja keuangan yang diukur dengan current rasio, working capital to asset ratio, return on investment, dan return on equity antara sebelum dan sesudah menerima penghargaan ISRA 2007.

Hasil penelitian ini menunjukkan bahwa wacana tentang sustainability reporting masih belum direspon oleh masyarakat khususnya investor di Indonesia .Hal ini disebabkan karena masih ada poin point lain selain terdaftarnya perusahaan menajadi partisipan ISRA yang menjadi perhatian investor untuk berinvestasi di Perusahaan Meskipun demikian bukan berarti sustainability reporting awards ini tidak penting, karena dinegara-negara maju perusahaan yang besar tidak berani untuk mengabaikan hal ini, bahkan masyarakat dan investor pun sangat mengutamakan hal ini (Sanjaya,2007). Oleh sebab itu wacana tentang sustainability reporting awards di Indonesia harus tetap dikembangkan dan dipertahankan mengingat begitu pentingnya laporan tersebut sebagai bentuk akuntabilitas perusahaan terhadap stakeholder mereka.

\section{KESIMPULAN DAN SARAN}

Berdasarkan hasil pengujian statistik dan analisis yang telah dibahas pada bab sebelumnya, Penelitian ini bertujuan untuk menguji apakah terdapat perbedaan kinerja perusahaan sebelum berpartisipasi dalam ISRA dengan sesudah berpartisipasi dalam ISRA pada tahun 2007 sampai 2011 dan mencakup 13 sampel perusahaan dengan menggunakan rasio keuangan yakni rasio profitabilitas.Adapun rasio-rasio keuangan tersebut antara lain Operating Return on Asset (ROA),Return on Equity (ROE),Net Profit Margin (NPM)Berdasarkan hasil dari uji beda t (pairedsamples $t$ test) hasil penelitian pada bagian sebelumnya, maka diperoleh kesimpulan penelitian ini adalah :

Pengujian yang dilakukan untuk hipotesis $\mathrm{H}_{1}, \mathrm{H}_{2}, \mathrm{H}_{3}$ dengan variabel kinerja keuangan perusahaan Rasio Profitabilitas yaitu ROA,ROE,dan NPM membuktikan bahwa tidak terdapat perbedaan yang signifikan pada perusahaan sebelum dan sesudah berpartisipasi dalam ISRA.

Hasil penelitian ini menunjukkan bahwa wacana tentang sustainability reporting masih belum direspon oleh masyarakat khususnya investor di Indonesia .Hal ini disebabkan karena masih ada poin point lain selain terdaftarnya perusahaan menajdi partisipan ISRA yang menjadi perhatian investor untuk berinvestasi di Perusahaan. Meskipun demikian bukan berarti bahwa sustainability reporting awards ini tidak 
penting, karena dinegara-negara maju perusahaan yang besar tidak berani untuk mengabaikan hal ini, bahkan masyarakat dan investor pun sangat mengutamakan hal ini. Oleh sebab itu wacana tentang sustainability reporting awards di Indonesia harus tetap dikembangkan dan dipertahankan mengingat begitu pentingnya laporan tersebut sebagai bentuk akuntabilitas perusahaan terhadap stakeholder mereka.

Saran yang dapat penulis sampaikan yaitu :

Bagi peneliti selanjutnya dapat melakukan penambahan variabel kinerja keuangan perusahaan selain dari variabel yang pernah diteliti sebelumnya.

Penelitian berikutnya dapat memperpanjang periode jendela penelitian agar dapat di peroleh jumlah sampel yang lebih banyak dan hasil penelitian yang lebih baik secara statistik.

\section{REFERENSI}

[1] Arthini, N W S \& Mimba, N P S H. 2016.Analisis Perbedaan Kinerja Keuangan antara Pemenang dan Bukan Pemenang ISRA.Fakultas Ekonomi dan Bisnis, Universitas Udayana,Bali. E.Jurnal akuntansi Universitas Udayana 8.3 Vol.14.1

[2] Dewi K.E.C dan Sudana I.Putu. 2015. SustaInability Reporting danProfitabilitas (Studi Pada Pemenang Indonesia Sustainability Reporting Awards).

[3] Firmani,Sheila Yunistia. 2013. Analisis Perbedaan Kinerja Keuangan Perusahaan antara Sebelum dan Sesudah Berpartisipasi dalam ISRA Selama Periode 2007-2011.e.jurnalunesa.ac.id

[4] Fitriana U. 2010.Analisis Kinerja Keuangan Perusahaan Sebelum dan Sesudah Pengumuman ISRA 2007. Fakultas Ekonomi Universitas Sebelas Maret, Surakarta.

[5] Ghozali, Imam. 2006. Aplikasi Analisis Multivariate dengan program SPSS Edisi Empat. Semarang :Badan Penerbit Universitas Diponegoro.

[6] Ikhsan, Adhisyah fitri Evalina. 2011. Analisis Kinerja Perusahaan: Sebelum dan Sesudah Intitial Publik Offering Di Bursa Efek Indonesia. Jurnal Ekonomi, Vol. 14 N0. 1 Januari 2011.

[7] Kusuma, Agung Budi. 2013. Asosiasi Pengungkapan CSR dan Kinerja Keungan pada Perusahaan Peraih Penghargaan Indonesia Sustainability Reporting Awards (ISRA) Periode 2011 danTerdaftar Di Bei2011-2012.

[7] Murhadi, Werner.R (2013). Analisis Laporan Keuangan Proyeksi Dan Valuasi Saham. Jakarta :Salemba Empat.

[8] Natalia, Riadan Tarigan, Josua. 2014. Pengaruh Sustainability Reporting Terhadap Kinerja Keuangan Perusahaan Publik Dari Sisi Profitability.Akuntansi Bisnis Universitas Kristen Petra.

[9] NCSR.2008. Report of the Judges Indonesia Sustainability Reporting Awards 2008. 
[10] Nofianto, Ekodan Agustina, Linda. 2014. Analisis PengaruhS ustainability Reporting terhadap KinerjaKeuangan. http://journal .unnes.ac.id/sju/index.php.aaj. (Diakses padatanggal 24 Agustus 2016 jam 11.13 WIB)

[11] Riduwan, dkk. 2011. Cara MudahBelajar SPSS 17.0 dan Aplikasi Statistik Penelitian. Bandung :Alfabeta.

[12] Sanjaya, Anton. 2007. Analisis Tingkat Profitabilitas Perusahaan Sebelum dan Sesudah Pelaksanaan Sustainability Reportingpada PT Astra Internasional Tbk. Http:// respositpory.widyatama..ac.id./xmlui/handle/123456789/7131. (Diaksespadatanggal 24Agustus 2016 jam 11.17 WIB)

[13] Santoso, Singgih. 2001. SPSS Mengolah Data Statistik Secara Profesional Versi 7.5. ElexJakarta : Media Komputindo.

[14] Susilowati dan Amanah.2013.Analisis Kinerja Keuangan Sebelum Dan Sesudah Go Public. Jurnal Ilmu \& Riset Akuntansi Vol. 2 No. 3 (2013)

[15] Sugiyono. 2014. Metode Penelitian Kuantitatif Kualitatif dan R \& D. Alfabeta : Bandung.

[16] Widyastuti \& Tarigan, Josua. 2014. Analisis Perbedaan Kinerja Keuangan (Market Ratio) Pada Perusahaan Partisipan ISRA Periode 2009-2011.

[17] Wijaya, Maria. 2012. Faktor-faktor yang mempengaruhi Pengungkapan Tanggung Jawab Sosial Pada Perusahaan Manufaktur y ang Terdaftar Di Bursa Efek Indonesia. Jurnal Ilmiah Mahasiswa Akuntansi-Vol.1.No.2

[18] www.antam.com/ (Ditelusuri tanggal 12-09-2016 Pukul 22.16)

[19] www.astra.co.id/Investor-Relations/Annual-Report (Ditelusuri tanggal 1209-2016 Pukul 22.08)

[20] www.bakriesumatera.com/index.php/en/investor-relations/annual-report (Ditelusuri tanggal 5-09-2016 Pukul 14.42)

[21] www.bumn.go.id/gasnegara/berita/kategori/134/Laporan.Tahunan (Ditelusuri tanggal 12-09-2016 Pukul 22.06)

[22] www.cimbniaga.com/in/personal/index.html (Ditelusuri tanggal 6-09-2016 Pukul 08.18)

[23] www.media.corporater.net/media_files/IROL/14/146157/ AR_MANDIRI_2011_A.pdf (Ditelusuri tanggal 5-09-2016 Pukul 13.57)

[24] www.component.astra.co.id/investor.asp?id=2\&lang=EN (Ditelusuri tanggal 12-09-2016 Pukul 22.40)

[25] www.file51A50BB6BC35D8B475CB3F1933182977.pdf

[26] www.indonesiapower.co.id/SitePages/Reports.aspx(Ditelusuritanggal 11 agustus jam 14.03)

[27] www.isra.ncsr-id.org (Ditelusuritanggal 26 Juni 2012 jam 18.13 WIB).

[28] www.media.corporateir.net/media_files/irol/20/202896/2013/2012_ laporan_tahunan_pgn.pdf (Ditelusuritanggal 05-09-2016 Pukul 14.56) 
[29] www.pep.pertamina.com/Tentang-PEP/Laporan-Tahunan (Ditelusuri tanggal 6-09-2016 Pukul 08.34)

[30] www.ptba.co.id/id/investor\#annual (Ditelusuri tanggal 5-09-2016 Pukul 13.3) 